\title{
Topics of Animal and Human Respiratory System of the Fifth Grade Elementary Schools Developed Through Pop-Up Book Media
}

\author{
Komang Triana Tantra Putra \\ The Study Program of Primary School Education Teachers, FIP, Ganesha University of Education, Indonesia \\ Email: trianakomang99@gmail.com
}

Desak Putu Parmiti

The Study Program of Primary School Education Teachers, FIP, Ganesha University of Education, Indonesia Email: dp_parmiti@undiksha.ac.id

\section{A R T I C L E I N F O \\ Article history: \\ 1 Maret 2020 Received in revised form \\ 30 Maret 2020 \\ Accepted 11 April 2020 \\ Available online 15 \\ Mei 2020}

\section{Kata Kunci:}

Pernapasan hewan,

manusia, pop-up book

Keywords: animal and human respiratory system, Pop-Up book

\begin{abstract}
A B S T R A K
Pelaksanaan penelitian ini didasarkan pada masalah yang ditemui, yaitu materi pada buku siswa masih kurang luas dan dangkal misalnya keterbatasan contoh-contoh yang ada di buku siswa dan penjelasan yang terlalu singkat dalam satu materi bahasan. Salah satunya pada topik sistem pernapasan hewan dan manusia. Penelitian ini bertujuan untuk mengembangkan media pop-up book pada topik sistem pernapasan hewan dan manusia. Selain itu hasil wawancara menunjukkan bahwa pemanfaatan media dalam pembelajaran masing kurang. Penelitian ini dilaksanakan dengan model ADDIE yang terdiri dari lima tahapan, yaitu: (1) analisis, (2) perancangan, (3) pengembangan, (4) implementasi, dan (5) evaluasi. Akan tetapi, pada penelitian ini tahap implementasi dan evaluasi tidak dilaksanakan karena keterbatasan waktu, biaya, dan sumber daya. Subjek penelitian ini adalah media pop-up book. Objek penelitian ini adalah validitas media pop-up book. Metode pengumpulan data dalam penelitian ini adalah kuesioner. Untuk mengukur validitas pop-up book, digunakan instrumen rating scale berupa lembar penilaian validasi media pop-up book. Data validitas media pop-up book dianalisis menggunakan rumus mean untuk mengetahui skor rata-rata validitas media. Penelitian
\end{abstract} ini menghasilkan media pop-up book topik sistem pernapasan hewan dan manusia dengan skor rata-rata 4.56 yang termasuk kategori "sangat baik". Hal ini berarti media pop-up book yang dikembangkan layak untuk digunakan. Media pop-up book ini menjadi solusi dari masalah keterbatasan materi pada buku siswa dan bisa dimanfaatkan oleh guru dalam menyampaikan materi pelajaran khusunya untuk topik sistem pernapasan hewan dan manusia kelas $\mathrm{V}$ sekolah dasar.

\begin{abstract}
A B S T R A C T
The implementation of this research was based on the problems encountered because the material in students' books was still less extensive in the limitation of examples and explanations on the students' books in one subject matter on the topic of animal and human respiratory system. This research aimed to develop Pop-Up book media on the topic of animal and human respiratory system. In addition, the results of the interviews showed that the use of media in learning was deficient. This research was carried out by using ADDIE model which was consisted of five phases, namely: (1) analysis, (2) design, (3) development, (4) implementation, and (5) evaluation. However, in this research the implementation and evaluation phases were not carried out due to time limitations, costs, and resources. The subject of this research was the Pop-Up book media. The object of this research was the validity of the Pop-Up book media. The data collection method was a questionnaire. The rating scale instrument was used in the form of validation assessment sheets to measure the validity of Pop-Up book. Data validity was analysed by using the mean formula to find out the average score of media validity. This research produced a Pop-Up book on the topic of animal and human respiratory systems with an average score of 4.56 which was categorized into very good category. It meant that Pop-Up book media was suitable to be used. It was a solution to the problem and could be used by teachers in delivering some materials.
\end{abstract}

\section{Introduction}

The curriculum has functions as a guideline, regulator, director, and adviser in educational activities so that the desired educational goals can be achieved (Rumahlatu, Huliselan, \& Takaria, 2016). Indonesia regularly changes the education curriculum. Currently in Indonesia, education applies 2013 curriculum. The 2013 curriculum promises to create creative, productive, innovative future generation with moral (Nurita, Musa, \& Yamin, 2018). It is because the 2013 curriculum pays attention to attitudes, skills, and knowledge competency that put them as equally important and equal (Ismayani \& Fauziya, 2019). To achieve this, the teacher's role is 
very necessary. In implementing the 2013 curriculum, the task of a teacher is to create an exciting learning atmosphere (Nurita et al., 2018). It can be done through the use of innovative learning methods and models that are in line with students' conditions and the supporting environment. The appropriate model will be able to increase students' activity in following the lessons. In addition, the teacher must provide complete learning materials and make students active (Nurita et al., 2018). Teaching materials can come from various things, one of them is from a book.

In the 2013 curriculum book, the subject matter is packaged in the form of a theme that contains a combination of various lesson content. It is because of the implementation of the 2013 curriculum in elementary schools through thematic learning. Thematic learning is defined as a learning activity by integrating the material of several subjects into one theme or topic of discussion. Thematic learning can also be interpreted as a learning activity by combining several content subjects in one discussion theme (Ananda \& Fadhilaturrahmi, 2018). It should be known that thematic learning emphasize on the implementation of the learning concept while doing something (learning by doing) (Qondias, Anu, \& Niftalia, 2016). Therefore, teachers need to design learning that can increase the meaningfulness of students' learning. One of them is by providing complete teaching material and activating students as well as encouraging students to act and utilize their senses as many as possible(Ambarsari \& Hartono, 2017).

However, in reality, the material contained in students' books is still relatively superficial and limited. One of them is on the science subject matter of the fifth grade. In fact, the students learn more about using students' books. This problem is reinforced from the results of observations and questionnaires distribution to the fifth grade of the elementary school teachers in cluster VIII of Sukasada sub-district in the academic year $2019 / 2020$ that was conducted on November $7^{\text {th }}, 2019$. The questionnaire results showed that $80 \%$ teachers stated that the content of science in students' books was still limited, $40 \%$ of the teachers also stated that the science content material in students' books was classified as superficial, and $20 \%$ stated that the science content material was very common, one of the topics was on animal and human respiratory system in the fifth grade in the odd semester. In addition, the results of syllabus analysis, teacher's book, and students' books showed that animal and human respiratory system material in the fifth grade was still relatively superficial, for example, the limitations of the examples in students' books, the lack of supporting images, and short explanation of a subject matter. Furthermore, the results of observations and interviews also showed that the use of media during the learning process was still lacking. It was due to inadequate infrastructure and facilities.

If this situation is not handled soon, students lack the existed subject matter and basic competencies of animal and human respiratory system material so that it cannot be achieved. It can affect students' learning outcomes. The wider impact is that the quality of education in Indonesia cannot improve and the graduates are lack quality. Therefore, innovation in developing the lacking subject matter is needed. Memorable learning will increase the meaningful learning of students. This impression can be generated through the use of media during the learning process (Ambarsari \& Hartono, 2017). Based on the problem, one solution that can be chosen is to develop the subject matter in the form of media for animal and human respiratory system material in the fifth grade in an odd semester. It was supported by the results of a questionnaire distribution in Elementary School VIII of Sukasada District. The results of the questionnaire showed that from 5 teacher respondents, $80 \%$ stated strongly agree if the material content of science in students' books was developed through the media, and the remaining $20 \%$ agreed to, as well as with students. From 15 existing student respondents, $73.3 \%$ stated that they strongly agreed if the material of science content in students' books was developed in the form of media, and $26.7 \%$ stated that they agreed if the material of science content in students' books was developed in the form of media.

Learning media is an important component in teaching and learning (Ambarsari \& Hartono, 2017). Learning media is a tool that is used to deliver messages easily from the source of the message to the recipient of the message in the learning process. Learning media influence the success of the learning process. The use of instructional media can arouse students' interests and desires in learning (Devi \& Maisaroh, 2017). It is because the media is packaged attractively to provide new experiences for students without reducing the benefits of the media. However, the selection of instructional media should not be careless. The use of appropriate learning media will help in delivering materials to the students(Hasmira, Anwar, \& Yusuf, 2017). Learning media are not only made interesting but also contain more systematic material so that learning is more effective. Therefore, teachers must be able to choose and determine the suitable media in teaching. The selection of media needs to be 
adjusted to its' needs, situations, and conditions (L. P. E. Sari, Ardana, \& Putra, 2016). It is done by using the used media to help students in learning. One of the media that can be developed is a pop-up book.

Pop-up books are three-dimensional learning media in the form of books with arising pictures when it is opened (Ambarsari \& Hartono, 2017). Pop-up book media has its charm because this media is a learning medium that can visualize forms created by folding, and moving, and appearing so that it gives an impressive and pleasing impression to students after opening each page (Safri, Sari, \& Marlina, 2017). The attractive appearance of the pop-up books can stimulate students' interest to learn (Sari \& Ulya, 2017). An interesting form of pop-up books can assist students in understanding the subject matter (Ahmadi, Fakharuddin, Trimurtini, \& Khasanah, 2018). Pop-up books media have the advantage of providing direct experience to students through students' involvement in sliding, opening, and folding the parts of pop-up books. It will give a special impression for students so that it can strengthen students' memories in learning with this media (Safri et al., 2017). Therefore, pop-up book media is suitable to be developed.

The studies on research and development media of pop-up books have been conducted by several researchers, but there is study has been conducted before for the topic of animals and humans the respiratory system so this study is new. A study conducted by Rahmi \& Fenny Agustina (2018) explained that the development of PBL-based invertebrate material based on pop-up book media is feasible to be conducted. In addition, a study conducted by Apriyanto \& Hidayat (2018) stated that the development of pop-up book media is feasible to be applied with "very good" category. Then, the results of a study conducted by Rahmawati (2018) stated that the validation level of the developed pop-up book was quite good. Furthermore, a study conducted by Ningtyas, et al., (2019) stated that the development of the generated pop-up book media was feasible to be applied. The four studies are in line with the present study. The connection among them can be seen from the valid result of the developed pop-up book media as well as it is suitable to be applied. Based on the explanation above, it can be seen that this study aimed at developing pop-up book media on the topic of animal and human respiratory systems in the fifth grade of elementary schools in cluster VIII of Sukasada in academic year 2019/2020. It has also proven its validity to be applied and it can overcome the problem of material limitations in the students' book.

\section{Method}

This study was a research and development of pop-up book media on the topic of animal and human respiratory system. This study applied the ADDIE model which consisted of five stages, namely: (1) analysis, (2) design, (3) development, (4) implementation, and (5) evaluation (Isya, 2017). However, the implementation and evaluation stages were not conducted due to the limitation of costs, time, and resources. In this study, the test subject was a pop-up book media on the topic of animal and human respiratory systems in the fifth grade of elementary school. The trial objects were the validity of the developed pop-up book media. The use of the ADDIE model was based on the consideration that the ADDIE model had a systematic and clear development process. In addition, the ADDIE model can be used to develop education and learning products so that the ADDIE model is suitable to be applied in the present study (Santosa, Santyadiputra, \& Divayana, 2017).

The first step in the ADDIE model is analysis. In the analysis stage, several analysis were conducted namely: (1) needs analysis including the observation and questionnaires distribution to the fifth grade teachers at SD (Elementary School) of Cluster VIII Sukasada regarding the content of science lesson and its development, (2) analysis of student characteristics was conducted to find out for the condition of students which later used pop-up book media, (3) curriculum analysis was done as a basic development of pop-up book media which was done through KI (core competency), KD (basic competency, achievement indicators, learning objectives, and subject matter analysis in students' books, and (4) media analysis was done by looking for guidelines about the criteria or characteristics of good media.

At the design stage, a pop-up book media design was developed. This stage began by determining the topic that was developed based on the results of the obtained analysis. Next, a pop-up book media design was made based on the basic competency that existed on the topic of animals and human's respiratory system. The next step was to consult the media design with the supervisor to get input and suggestions so that improvements could be made. After the results of the improvement were approved, the study was continued to the development stage.

At the development stage, a pop-up book media development was done that had been previously consulted with a supervisor. After the pop-up book media had been developed, a product trial was conducted to determine the validity of the developed media. The product trial was conducted through an expert test at the review stage by two lecturers and two teachers. The results of the review by experts were used as material for improvement/revision of the developed pop-up media. 
In this research and development, the method of data collection was questionnaire method. The questionnaire contained some questions or statements and suggestions related to the developed media. The instrument used a rating scale. The rating scale is the rating method based on a scale from low to high (Ilhami \& Rimantho, 2017). In this study, the scale used is 1-5. The rating scale method is very simple so it is easy to design and use. Respondents only need to answer or choose one of several answer numbers that have been provided (Ilhami \& Rimantho, 2017). The given assessment was based on reality. Before using it, an instrument was tested for eligibility. The feasibility of an instrument was determined from the results of the content validity test. The lattice of the pop-up book instrument was tested for the validity of its contents by judges. The assessment results were accumulated using the Gregory formula. In this study, the validity coefficient of the applied instrument obtained a value of 1.00. It means that the applied instrument to assess pop-up book media has very high validity.

The techniques of data analysis in this research and development where are qualitative descriptive and quantitative descriptive statistical analysis. A descriptive qualitative statistical analysis method was used to process data in the form of criticism, suggestions, and input from expert's reviews of developed pop-up book media through questionnaires. The results of the analysis were used to make improvements to the developed pop-up book media. A quantitative descriptive statistical analysis method was used to describe the average score of the developed pop-up book media. To find the average validity score of the developed media, it was based on the obtained scores from each indicator and the mean formula could be used. The obtained average score was converted using the five scale conversion guidelines to determine the validity of the developed media. Pop-up book media was stated to be valid if the average score obtained was at least in a good qualification with a range of $3.33<\mathrm{x} \leq 4.01$.

\section{Result and Discussion}

This study produced a pop-up book media on the topic of animal and human respiratory system in the fifth grade with a very good level of validity. These results were obtained through several stages of development consisting of the analysis, the design, and the development stage. In the analysis stage, several steps were conducted, namely: need analysis, student characteristics analysis, curriculum analysis, and media analysis. The results of the needs analysis showed that the material contained in science books with the topic of animal and human respiratory systems were limited and less extensive so the material needed to be developed. It was obtained based on observations and questionnaires distribution to the fifth-grade teacher of elementary school in Cluster VIII of Sukasada District. In addition, the results of the interviews showed that the use of media in learning was still lacking. Therefore, it is necessary to develop material on the topic of animal and human respiratory systems in the form of pop-up book media.

The results of student characteristics analysis indicated that the fifth-grade elementary school students in the Cluster VIII of Sukasada District were still at the concrete operational stage (6-12 years). At this age, children are capable enough to use logical thinking or operations, but only for tangible or physical objects that exist today (Ibda, 2015). Therefore, students must learn by using real objects so students better understand what is learned. Pop-up book media is very relevant to the level of cognitive development of the fifth grade elementary school students because pop-up books are concrete learning media in the form of three-dimensional books with arising pictures when it is opened (Ambarsari \& Hartono, 2017) so the development of pop-up books is very suitable to be applied. Furthermore, the results of curriculum analysis conducted through KI, KD analysis, achievement indicators, learning objectives, and subject matter in student books, reinforced the results of needs analysis which showed that the material in students' books especially on animal and human respiratory system was limited and less extensive examples such as the limitations of student's books example, lack of supporting images, and s short explanations in one subject matter. In other words, the material in students' books was still lacking.

The results of media analysis were attached to an assessment instrument that was used to measure the validity of the developed pop-up book media. In developing pop-up books, the attention must be given to the purpose of media use so that the developed media developed is in line with media usage goals. The purpose of using media in learning can be seen, namely: (1) stimulates student concentration on the lesson, (2) facilitates the learning process because the media can display tangible forms felt by students, and (3) as a carrier of information contains material instructional (Sari et al., 2016). The development of pop-up book media is based on the principle above.

At the design stage, a pop-up book media design was developed. This stage began by determining the developed topic based on the results of the analysis that had been done. The chosen topic was animal and human respiratory system. Next, a pop-up book media design was made. There were two designs, namely material design and media design. In the draft material, it was compiled the material to be used in media based on the main purpose of developing material through pop-up book media. In media design, it was done by using 
Photoshop CS 3 and Microsoft PowerPoint applications. The images were taken from the internet. The size of the paper was A5 paper $(14.85 \mathrm{~cm}$ x $21 \mathrm{~cm})$. In addition, techniques were also used on every page of the pop-up book. The various techniques were used based on the loaded material. There were some techniques, namely: (1) peepshow is a pop-up that is made by stacking several pieces of paper to cause the illusion of depth and perspective, (2) v-fold is a pop-up that is made with folded paper the shape of the letter V then it is adhered in the middle of the book so that when the book is opened there are parts that appear and stand, and (3) automatic pull tab is pop-up with sliding paper arranged in such a way and capable of causing automatic movements when the book is opened. The next step was to consult the media design with the supervisor to get input and suggestions so that improvements could be made.

Pada tahap pengembangan (development), dilakukan pengembangan media berdasarkan rancangan yang telah disetujui oleh dosen pembimbing. Bahan-bahan yang digunakan dalam membuat media pop-up book, yaitu kertas glossy, kertas stiker, art paper, dan double tape. Beberapa contoh gambar media pop-up book yang dikembangkan, disajikan pada Gambar 1 dan Gambar 2.

At the development stage, media development was based on a design that had been approved by the supervisor. The materials used in making media pop-up books, namely: glossy paper, sticker paper, art paper, and double-sided tape. Some examples of images of developed media pop-up books, were presented in Figure 1 and Figure 2.

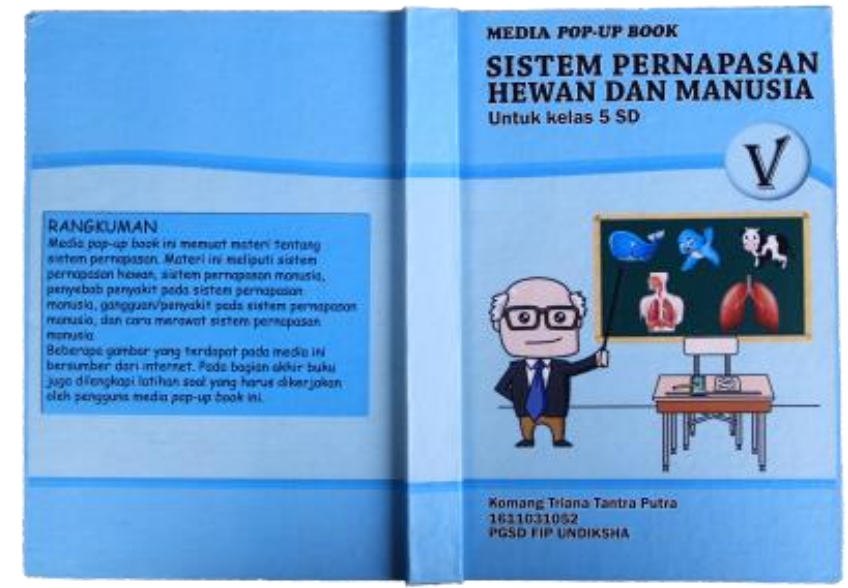

Figure 1.

The Cover of Pop-Up Book Media

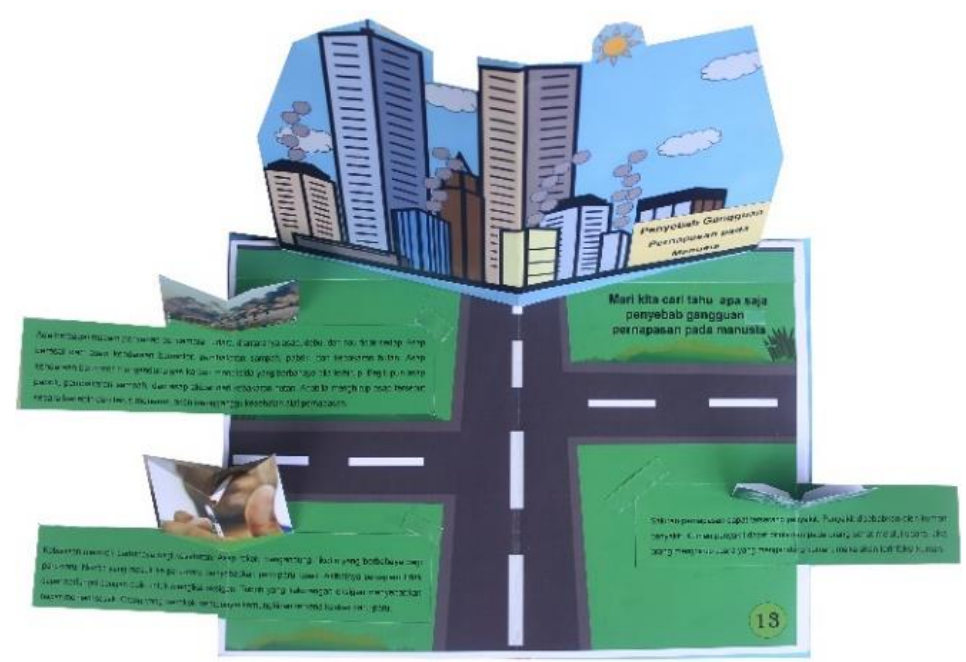

Figure 2.

The Material of Pop-Up Book Media

Pop-up book media consisted of 16 pages including covers, instruction, table of contents, KD \& Indicators, animal and human respiratory system material, and at the end of the page contained questions exercises. After the pop-up book media was finished, a product trial was carried out by four experts (two 
lecturers and two teachers) to determine the validity of the developed media. In the trial, it is also obtained criticisms and suggestions from experts on the developed pop-up book media. As for the criticisms and suggestions are given, namely: (1) there were some parts of the pop-up book that needed to be thickened/strengthened so that this media could be durable for use, for example, the material locking section, (2) it was necessary to pay attention to the selection of background colors on several pages. However, due to time, cost, manpower, and resources limitations, product revisions based on expert criticism and suggestions were still being considered. Furthermore, the results of the validity of the pop-up book media were presented in Table 1 .

Table 1. The Average Score of Pop-Up Book Media Validation and Qualification

\begin{tabular}{cccccccc}
\hline Aspect & $\mathbf{1}$ & $\mathbf{2}$ & $\mathbf{3}$ & $\mathbf{4}$ & Total & Average & Qualification \\
\hline 1 & 5 & 5 & 5 & 4 & 19 & 4.75 & Very Good \\
2 & 5 & 5 & 4 & 5 & 19 & 4.75 & Very Good \\
3 & 5 & 5 & 5 & 3 & 18 & 4.5 & Very Good \\
4 & 5 & 5 & 4 & 4 & 18 & 4.5 & Very Good \\
5 & 5 & 4 & 4 & 4 & 17 & 4.25 & Very Good \\
6 & 5 & 5 & 4 & 4 & 18 & 4.5 & Very Good \\
7 & 5 & 5 & 4 & 5 & 19 & 4.75 & Very Good \\
8 & 5 & 5 & 4 & 4 & 18 & 4.5 & Very Good \\
9 & 4 & 5 & 5 & 3 & 17 & 4.25 & Very Good \\
10 & 5 & 5 & 3 & 4 & 17 & 4.25 & Very Good \\
11 & 5 & 5 & 4 & 5 & 19 & 4.75 & Very Good \\
12 & 5 & 5 & 5 & 4 & 19 & 4.75 & Very Good \\
13 & 5 & 5 & 4 & 5 & 19 & 4.75 & Very Good \\
\hline Average & $\mathbf{4 . 9 2}$ & $\mathbf{4 . 9 2}$ & $\mathbf{4 . 2 3}$ & $\mathbf{4 . 1 5}$ & $\mathbf{1 8 . 2 3}$ & $\mathbf{4 . 5 6}$ & Very Good \\
\hline
\end{tabular}

Description

Aspect 1: Identity on the cover of the pop-up book.

Aspect 2: The attractiveness of the pop-up book cover.

Aspect 3: Harmony of colors, writing and pictures in the pop-up book.

Aspect 4: Harmony of use and font size.

Aspect 5: Conformity of the layout of the pop-up book media.

Aspect 6: The suitability of the material in the pop-up book with the learning indicators.

Aspect 7: Completeness of material/information contained in the pop-up book.

Aspect 8: The contents of the pop-up book media can arouse students' curiosity.

Aspect 9: Ease of understanding the language used.

Aspect 10: Language suitability based on Indonesian language rules.

Aspect 11: Effectiveness of sentence structure

Aspect 12: Ease of using pop-up book media.

Aspect 13: Pop-up book helps the teacher to explain the material.

Based on Table 1, it can be seen that the average score of all aspects of the pop-up book media based on the five scale conversion guidelines was in the range of $4.01<\mathrm{X} \leq 5.01$. It means that all aspects of the pop-up book are considered to have very good qualifications. Next, the average validity score given by each expert was presented in Figure 3. 


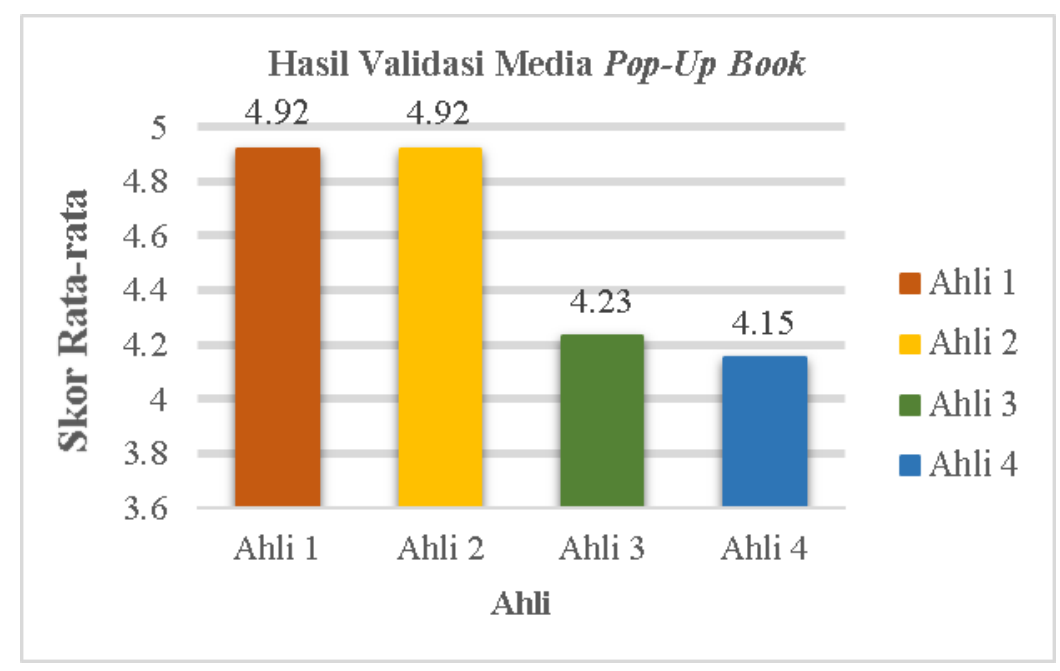

Figure 3.

The Diagram of Validity Average Score of Pop-Up Book

Based on Figure 3, it is known that the average score of media validation given by expert 1 was 4.92 , expert 2 was 4.92, expert 3 was 4.23, and expert 4 was 4.15 . These four scores were converted using the fivescale conversion guidelines in the range of $4.01<\mathrm{X} \leq 5.01$. It means that the developed pop-up book media are classified as very good based on the assessment of each expert. Likewise, overall, pop-up book media got an average score of 4.56. When it was converted using the five-scale conversion guidelines, this score was in the range of $4.01<\mathrm{X} \leq 5.01$ with very good qualifications. Developed pop-up book media have very good criteria seen from the assessment of each component, the assessment of each expert, and the overall average. Therefore, pop-up book media on the topic of animal and human respiratory systems are valid and ready to be applied

After going through the stages of development starting from analyse stage, design stage, and the development stage, pop-up book media on the topic of animal and human respiratory systems was produced. The development of this media referred to the findings in the field based on observations, questionnaires distribution, and also interviews conducted to the fifth grade elementary school teachers in Cluster VIII of Sukasada District. The developed pop-up book product has been based on the situation, conditions, and needs in the field so that this media is appropriate and able to overcome the problems, especially the lacking material in students' books on topic of animal and human respiratory systems and the use of media in learning. As it is known that the use of instructional media can arouse the desire of students to learn (Devi \& Maisaroh, 2017). It is because learning media are made to provide new experiences for students and can attract attention without reducing the benefits of these learning media. Therefore, pop-up book media is very suitable when it is used in learning because pop-up books are very interesting and can display/visualize various forms with various folding techniques so that it gives a good impression for students in using it (Safri et al., 2017).

In addition, the development of this media is done because the media is a channel of information/messages from the sender to the recipient of the message that can stimulate learning interest (Anggraeni \& Sukirno, 2019). When it is linked to teaching and learning activities, the media means a tool/intermediary to convey information from teachers to students (Arimbawa, Astra, \& Satyawan, 2017). In addition, the media also has meaning as a source of instructional learning that can stimulate students' interest in learning (Widianto, 2017). From these various meanings, it can be concluded that the media are all physical things that are used as a distributor of information/messages from the sender to the recipient of the message. Referring to this understanding, it appears that media development is very appropriate to be implemented, one of which is pop-up books because pop-up books are 3D learning media in the form of books with arising pictures when it is opened (Ambarsari \& Hartono, 2017). Pop-up books are able to visualize something through the pictures in it. The attractive appearance of the pop-up book can stimulate students' interest to learn (Sari \& Ulya, 2017). Likewise, in the developed pop-up book media contained material especially the topic of the respiratory system of animals and humans accompanied by interesting drawings that are designed in such a way and used as tools/intermediaries to facilitate the material delivery. The development of pop-up book media is also based on the important function of media. In the world of education, the media have functions as a means of achieving the 
expected learning goals (Arimbawa et al., 2017). The function of media in learning includes: (1) helping to accelerate student understanding, (2) increasing student interest, (3) utilizing the availability of space, (4) clarifying verbal messages, (5) learning time can be conditioned, (6) more learning productive and communicative, (7) eliminating student boredom, (8) increasing passion and motivation, and (9) facilitating diverse learning styles of students (Tanrere \& Side, 2012). Considering this, it can be said that the development of pop-up books media on the topic of the respiratory system of animals and humans is appropriate.

Then, when it was viewed from the stage of cognitive development, the fifth-grade elementary school students were at a concrete operational stage (7-12 years). At this stage, students more easily understand a concept through concrete experiences (Desstya, Novitasari, Razak, \& Sudrajat, 2017). A concrete experience can be obtained through the use of pop-up book media in learning because its function is to clarify the verbal message to be more concrete and it contains pictures to help in visualizing an abstract explanation so the development of pop-up book media is in line with the student characteristics of elementary school. In addition, the results of this study were consistent with constructivism learning theory which emphasizes that knowledge is built by students through direct experience. It causes students' understanding increase due to direct involvement in shaping their knowledge (Santosa et al., 2017). It is in line with the theory of constructivism learning because in the use of this pop-up book, students are directly involved in reading, opening, and folding the media, thus providing direct experience for students, their impressions and being able to increase students' understanding in learning especially on animal and humans respiratory system material.

The pop-up media book on the topic of animal and human respiratory system was valid and proper to be applied. This result was obtained from the average score of media validity. This score was obtained through the evaluation of four experts (two lecturers and two teachers). The average validity score was given by each expert, namely: (1) expert 1 at 4.92, (2) expert 2 at 4.92, (3) expert 3 at 4.23 , and (4) expert 4 at 4.15 . The four scores were converted using the five-scale conversion guideline and it showed in the range of $4.01<\mathrm{X} \leq 5.01$. It means that the developed pop-up book media are classified as very good based on the assessment of each expert. Then, its average score of each aspect was assessed and converted based on a five-scale conversion guideline. It showed at the range of $4.01<\mathrm{X} \leq 5.01$. It means that all aspects of the pop-up book are considered to have very good qualifications. Likewise, overall, the developed pop-up book obtained an average validity score of 4.56. This score is classified as very good based on the five scale conversion guidelines. In other words, the developed pop-up book media have very good criteria in terms of component/aspect assessment, the assessment of each expert, and the overall average. Therefore, pop-up book media on the topic of animal and human respiratory systems are valid and ready to be applied.

The development of media pop-up book had been done before by several researchers, and the results were used as a support in this study, but for the development of pop-up books on topic of animal and human respiratory systems has never been done before so this research is new. The results of the study conducted by Rahmi \& Agustina (2018) explained that the scope of the development of PBL-based invertebrate material popup book was worth to be applied. These results were obtained from testing the quality of the media by 3 validators. The final results were obtained at $85.36 \%$. It means the developed media is valid. Another study conducted by Ningtiyas, Setyosari, \& Praherdiono, (2019) stated that the development of the pop-up book media was valid and appropriate to be used. It can be seen from the level of validity based on the results of the calculation of media experts at $96.59 \%$ and based on the assessment of material experts at $97.36 \%$. Both of these results are in line with this study which states that the pop-up book media on the topic of animal and human respiratory systems has very good qualifications and it is valid.

Media pop-up boo topik sistem pernapasan hewan dan manusia ini terdiri dari 16 halaman yang meliputi: sampul, petunjuk penggunaan, $\mathrm{KD}$, indikator, daftar isi, materi sistem pernapasan hewan dan manusia, dan latihan soal. Adapun kelebihan media pop-up book topik sistem pernapasan hewan dan manusia, yaitu: (1) dapat mempermudah guru dalam menyampaikan materi khususnya topik sistem pernapasan hewan dan manusia, (2) mampu meningkatkan minat serta daya tarik siswa untuk belajar, (3) mampu meningkatkan keterlibatan siswa saat proses pembelajaran, (4) penggunaan pop-up book memberikan pengalaman baru bagi siswa saat belajar. Media pop-up book ini memiliki kekurangan yaitu belum diujicobakan di kelas.

Pop-up boo media on topic of animal and human respiratory system consisted of 16 pages which include: cover, instructions, KD, indicators, table of contents, animal and human respiratory system material, and exercises. The advantages of pop-up book media on the topic of animal and human respiratory systems, namely: 
(1) can facilitate teachers in delivering material, especially the topic of animal and human respiratory systems, (2) increase the student interest and attractiveness to learn, (3) increase student involvement during the learning process, (4) the use of pop-up books provides a new experience for students in learning. This pop-up book media has the disadvantage that it has not been tried out in class.

\section{Conclusion and Suggestion}

Berdasarkan hasil penelitian dan pembahasan, dapat disimpulkan bahwa media pop-up book pada topik sistem pernapasan hewan dan manusia kelas $\mathrm{V}$ dinyatakan valid dengan rata-rata skor sebesar 4.56 dan tergolong sangat baik. Hal ini berarti media pop-up book layak digunakan untuk membantu guru maupun siswa dalam membahas materi khususnya sistem pernapasan hewan dan manusia. Selain itu, media pop-up book ini juga menjadi solusi untuk masalah keterbatasan materi yang terdapat pada buku siswa khususnya untuk topik sistem pernapasan hewan dan manusia. Media ini sesuai dengan karakteristik siswa kelas V SD yang berada pada tahap operasional konkret dan memerlukan benda-benda bersifat nyata atau konkret saat belajar. Hal ini dikarenakan media pop-up book mampu memvisualisasikan bentuk-bentuk yang dibuat dengan melipat, bergerak, dan muncul sehingga memberikan kesan bagi siswa saat belajar menggunakan media ini. Media ini juga sesuai dengan teori belajar konstruktivisme yang menekankan keterlibatan siswa secara langsung dalam membangun atau menemukan pengetahuannya sendiri. Berdasarkan penelitian yang telah dilakukan, dapat disampaikan beberapa saran, yaitu: (1) kepada guru, bisa menggunakan media pop-up book dalam menyampaikan materi khususnya pada topik sistem pernapasan hewan dan manusia, (2) kepada kepala sekolah, diharapkan mampu mengarahkan serta memfasilitasi guru lain guna mengembangkan media pembelajaran serupa, (3) kepada peneliti lain yang memiliki penelitian serupa, bisa menjadikan penelitian ini sebagai referensi ataupun melanjutkan penelitian ini pada tahap implementation serta evaluation.

Based on the results and discussion of the study, it can be concluded that the pop-up book media on the topic of animal and human respiratory system in the fifth grade is valid with an average score of 4.56 and it is classified as very good. It means that the pop-up book media is appropriate to be used for helping teachers and students to discuss material, especially on topic of animal and human respiratory systems. In addition, this popup book media is also a solution to the problem of material limitations contained in students' books, especially for the topic of animal and human respiratory systems. This media is suitable for the characteristics of the fifith grade elementary school students who are at a concrete operational stage and need tangible or concrete objects in learning. It is because the pop-up book media can visualize forms created by folding, moving, and appearing to give an impression to students in learning assisted with this media. It is also in line with the theory of constructivism learning which emphasizes the direct involvement of students in building or finding their knowledge. Based on research that has been done, several suggestions can be conveyed, namely: (1) for teachers, pop-up book media can be used to deliver material, especially on the topic of animal and human respiratory systems, (2) for the principal, it is expected to be able to direct and facilitate other teachers to develop similar learning media, (3) for other researchers who have similar research, this research can be as a reference or continue this research at the implementation and evaluation stages.

\section{References}

Ahmadi, F., Fakharuddin, Trimurtini, \& Khasanah, K. (2018). The Development of Pop-Up Book Media to Improve 4th Grade Student's Learning Outcomes of Civic Education. Asia Pacific Journal of Contemporary Education and Communication Technology, 4(1), 43-50. https://doi.org/10.25275/apjcectv4i1edu5

Ambarsari, D. W., \& Hartono, B. (2017). Pengembangan Media Pop Culture Up Rumah Adat Jawa Untuk Pembelajaran Menyusun Teks Deskripsi Pada Peserta Didik Smp Kelas Vii. Semantik, 6(2), 1-9. https://doi.org/10.22460/semantik.v6i2.p1-10

Ananda, R., \& Fadhilaturrahmi. (2018). Analisis Kemampuan Guru Sekolah Dasar Dalam Implementasi Pembelajaran Tematik di SD. Jurnal Basicedu, 2(2), 11-21. https://doi.org/10.31004/basicedu.v2i2.42

Anggraeni, D. N., \& Sukirno. (2019). Media Pembelajaran Pop-up Box Simulasi Myob Accounting pada Mata Pelajaran Komputer Akuntansi. Jurnal Pendidikan Akuntansi Indonesia, 17(1), 16-30. 
Apriyanto, S., \& Hidayat, P. (2018). Pengembangan Pop-Up Book Dalam. Fundamental Pendidikan Dasar, $1(1), 1-18$

Arimbawa, I. G. A. A., Astra, I. K. B., \& Satyawan, I. M. (2017). Pengaruh Penerapan Model Pembelajaran Kooperatif Tipe STAD Berbantuan Media Gambar terhadap Hasil Belajar Teknik Dasar Passing Sepak Bola. E-Journal PJKR, 8(2), 1-9.

Desstya, A., Novitasari, I. I., Razak, A. F., \& Sudrajat, K. S. (2017). Refleksi Pendidikan Ipa Sekolah Dasar Di Indonesia (Relevansi Model Pendidikan Paulo Freire dengan Pendidikan IPA di Sekolah dasar). Profesi Pendidikan Dasar, 4(1), 1-11. https://doi.org/10.23917/ppd.v1i1.2745

Devi, A. S., \& Maisaroh, S. (2017). Pengembangan Media Pembelajaran Buku Pop-Up Wayang Tokoh Pandhawa Pada Mata Pelajaran Bahasa Jawa Kelas V SD. Jurnal PGSD Indonesia, 3(2).

Hasmira, Anwar, \& Yusuf, M. (2017). Penggunaan Media Pembelajaran Video Animasi untuk Meningkatkan Hasil Belajar PKn pada Siswa Kelas IV di SD Negeri 1 Ngapa. Jurnal Wahana Kajian Pendidikan IPS, 1(2), 128-137.

Ibda, F. (2015). Perkembangan Kognitif: Teori Jean Piaget. Intelektualita, 3(1), 27-38.

Ilhami, R. S., \& Rimantho, D. (2017). Jurnal Optimasi Sistem Industri Penilaian Kinerja Karyawan dengan Metode AHP dan Rating Scale. Jurnal Optimasi Sistem Industri, 16(2), 150-157.

Ismayani, R. M., \& Fauziya, D. S. (2019). Pelatihan Kurikulum 2013 di Tingkat Sekolah Dasar. Jurnal Pengabdian Kepada Masyarakat (Abdimas), 02(01), 11-16.

Isya, M. A. (2017). Pengembangan model pembelajaran instruksional design dengan model Addie mata pelajaran PAI pada materi mengulang-ulang hafalan Surah Al Ma'un dan al Fil secara klasikal, kelompok dan individu kelas V SDN Gedongan 2 Kota Mojokerto. Jurnal Ilmiah Pendidikan Agama Islam, 7(1), 7180. https://doi.org/10.32616/tdb.v7i1.37

Ningtiyas, T. W., Setyosari, P., \& Praherdiono, H. (2019). Pengembangan Media Pop-Up Book Untuk Mata Pelajaran Ipa Bab Siklus Air Dan Peristiwa Alam Sebagai Penguatan Kognitif Siswa. Jurnal Kajian Teknologi Pendidikan, 2(2), 115-120. https://doi.org/10.17977/um038v2i22019p115

Nurita, N. M., Musa, I., \& Yamin, M. (2018). Kendala-kendala Guru Dalam Mengimplementasikan Kurikulum 2013 Di SD Negeri 7 Teupah Barat Kabupaten Simeuleu. Jurnal Ilmiah Pendidikan Guru Sekolah Dasar, $3(4), 111-118$.

Qondias, D., Anu, E. L., \& Niftalia, I. (2016). Pengembangan Media Pembelajaran Tematik Berbasis Mind Maping SD Kelas III Kabupaten Ngada Flores. JPI (Jurnal Pendidikan Indonesia), 5(2), 176-182. https://doi.org/10.23887/jpi-undiksha.v5i2.8590

Rahmawati, D. (2018). Pengembangan Media Pembelajaran Pop Up Book Pada Materi Perubahan Wujud Benda Untuk Siswa SDLB Tunarungu Kelas IV. Jurnal Widia Ortodidaktika, 7(2), 186-196.

Rahmi, \& Agustina, F. (2018). Pengembangan Media Pop Up Book (Bilingual) Dengan Pendekatan Model Problem Based Learning (PBL) Terhadap Hasil Belajar Siswa SMAN 10 Kelas X Kota Batam. Simbiosa, 7(2), 122-133. https://doi.org/10.33373/sim-bio.v7i2.1462

Rumahlatu, D., Huliselan, E. K., \& Takaria, J. (2016). An analysis of the readiness and implementation of 2013 curriculum in the west part of Seram District, Maluku Province, Indonesia. International Journal of Environmental and Science Education, 11(12), 5662-5675.

Safri, M., Sari, S. A., \& Marlina. (2017). Pengembangan Media Belajar Pop-Up Book pada Materi Minyak Bumi. Jurnal Pendidikan Sains Indonesia, 05(01), 107-113.

Santosa, A. S. E., Santyadiputra, G. S., \& Divayana, D. G. H. (2017). Pengembangan E-Modul Berbasis Model Pembelajaran Problem Based Learning pada Mata Pelajaran Administrasi Jaringan Kelas XII Teknik Komputer Dan Jaringan di SMK TI Bali Global Singaraja. Kumpulan Artikel Mahasiswa Pendidikan Teknik Informatika (KARMAPATI), 6(1), 62-72. https://doi.org/10.23887/karmapati.v6i1.9269

Sari, L. P. E., Ardana, I. K., \& Putra, D. K. N. S. (2016). Penerapan Metode Bercerita Berbantuan Media Gambar Berseri untuk Meningkatkan Kemampuan Bercerita pada Anak Kelompok A1. Jurnal Pendidikan Anak Usia Dini, 4(1).

Sari, S. A., \& Ulya, A. (2017). The Development of Pop-up Book on the Role of Buffer in the Living Body. European Journal of Social Sciences Education and Research, 4(4), 213-221. 
https://doi.org/10.26417/ejser.v10i2.p213-221

Tanrere, M., \& Side, S. (2012). Pengembangan Media Chemo-Edutainment Melalui Software Macromedia Flash Mx pada Pembelajaran IPA Kimia SMP. Jurnal Pendidikan Dan Kebudayaan, 18(2), 156-162.

Widianto, E. (2017). Media Wayang Mini dalam Pembelajaran Keterampilan Berbicara bagi Pembelajar BIPA A1 Universitas Ezzitouna Tunisia. Jurnal Kredo, 1(1), 120-142. 